\title{
FAKTOR DETERMINAN FINANCIAL DISTRESS UNTUK PERUSAHAAN PERTAMBANGAN DI INDONESIA DAN MALAYSIA
}

\author{
Arief Bagas Prasetyo \\ Program Studi Akuntansi Universitas Telkom \\ ariefbagasp@students.telkomuniversity.ac.id \\ Farida Titik Kristanti \\ Program Studi Akuntansi Universitas Telkom \\ faridatk@telkomuniversity.ac.id
}

\begin{abstract}
Abstrak: Faktor determinan Financial Distress Untuk Perusahaan Pertambangan Di Indonesia dan Malaysia. Studi ini bermaksud untuk mengetahui dampak likuiditas, leverage, operating capacity, instittutional ownership, managerial ownership, sertakomisaris independen padaFinancial Distress. Penelitian ini memakai penelitian deskriptif. Populasi serta sampel pada studi ialah perseroan sektor pertambangan yang tercatat di BursaEfek Indonesia dan Bursa Malaysia 2014-2018. Studi ini memakai purposive sampling serta diperoleh 12 perseoran di Indonesia dan 22 perseroan di Malaysia. Olah data yang dipakai studi ini memakai logistic regression. Studi menunjukkan pada perseroan pertambangan di Indonesia bahwa operatingcapacity scara parsial mempunyai pengaruh signifikan negatif pada financial distress. Sedangkan liquidity, leverage, institutional ownership, managerial ownership, dan independent comissioner secara parsial tidak mempunyai pengaruh pada financial distress. Kemudian pada perseroan pertambangan di Malaysia menunjukkan bahwa liquidity, Managerial Ownership, dan Independent Commissioner secara parsial mempunyai pengaruh signifikan negatif pada financial distress. Sedangkan operating capacity,leverage, dan Institutional Ownership secara parsial tidak mempunyai pengaruh pada financial distress.
\end{abstract}

Kata kunci: Liquidity, Leverage, OperatingCapacity, Institutional Ownership, Managerial Ownership, Independent Commissioner, Financial Distress

Abstract: Determinants ofFinancial Distressfor Mining Companies in Indonesia and Malaysia. Research intend todetermine the impact ofliquidity, leverage, operatingcapacity, institutional ownership, managerialownership, and independent commissioner onfinancial distress. This research uses descriptive research. Thepopulation and sample are miningsector firm registered onthe IDX and Malaysia Exchange 2014-2018. This study uses purposivesamplingmethod acquired 12 companies in Indonesia and 22 companies in Malaysia. The data processing techniques used logisticregression. Research showed mining companies in Indonesia that their operating capacityhas a negative impact on financial distress. Whereas, liquidity,leverage, institutionalownership, managerialownership, and the independentcommissioner didn't have affects onfinancial distress. Then the mining companies in Malaysia showed that liquidity, Managerial Ownership, and Independent Commissionerhave a negative impact onfinancial distress. Meanwhile, operating capacity, leverage, and institutional ownership didn't have affects on financial distress.

Keywords: Liquidity, Leverage, OperatingCapacity, Institutional Ownership, Managerial Ownership, Independent Commissioner, Financial Distress

\section{PENDAHULUAN}

Dengan berkembangnya perekenomian dikala ini, perusahaan dituntut untuk bisa bersaing dengan menunjukkan berbagai keunggulannya dengan para kompetitornya

baik dengan perseroan dalam negeri ataupun perseroan asing. Ketatnya persaingan dapat mengakibatkan keadaan kesulitan keuangan hingga dilikuidasiapabila perusahaan tidak 


\section{Nominal: Barometer Riset Akuntansi dan Manajemen \\ P-ISSN: 2303-2065 E-ISSN: 2502-5430 \\ Volume 10 No 2 (2021)}

mampu bertahan. Kesulitan keuangan yang berlarut- larut hendak semakin parah serta mengakibatkan kebangkrutan.

Financial distress ialah sesuatu kondisi dimana perseroan yang lagi terletak di dalamnya hadapi penyusutan keuntungan. Industri yang hadapi penyusutan laba ataupun arus kas yang mempunyai nilai kecil bisa dikategorikan masuk kedalam keadaan financialdistress. Financial distress ialah sesi sangat dini dikala industri dalam masa kesusahan keuangan saat sebelum terbentuknya kebangkrutan (Syofyan \& Herawaty, 2019). Sejumlah faktor yang mampu menyebabkan perseroan mengalami financial distress, diantaranya faktor dari internal dan dari eksternal perseroan. Faktor dari internal perseroan seperti kuantitas serta kualitas sumberdaya manusia yang tidak memadai, anggaran yang tidak sesuai dengan kondisi perseroan, pemasaran dan distribusi produk yang buruk, serta berbagai faktor internal lainnya. Adapun dari faktor eksternal seperti lingkungan sosial budaya, kondisi ekonomi makro yang berupa pertumbuhan ekonomi dan inflasi, serta bencana alam yang menyebabkan kegagalan bisnis suatu perseroan (Kristanti, 2019:13).

Elloumi dan Gueyie (2001) menyatakan bahwa perseroan yang mengalami financial distress apabila perseroan mempunyai Earning per Share (EPS) negatif. Karena keuntungan dan kerugian yang diperoleh perseroan pada tahun yang bersangkutan dapat menggambarkan kinerja perseroan pada periode sebelumnya serta prospek berikutnya perseroan mampu tergambarkan dengan EPS (Widhiari \& Merkusiwati, 2015).

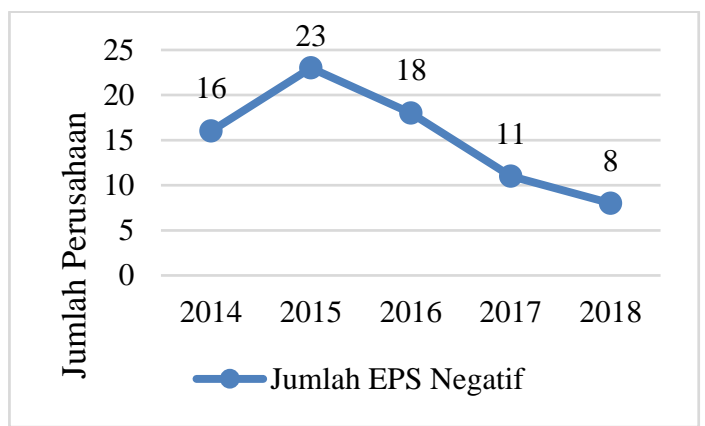

Gambar 1: Earning Per Share (EPS)

Perseroan Pertambangan Indonesia

Gambar 1 memvisualisasikan bahwa jumlah perseroan pertambangan di Indonesia yang mempunyai EPS negatif berfluktuatif serta cenderung meninggi. Dari 47 perseroan yang terdaftar di BEI, tahun 2015 perseroan yang mempunyai EPS negatif sebanyak 23 perseroan, sedangkan 18 industri mempunyai EPS negatif pada tahun 2016, 15 perseroan mempunyai EPS Negatif pada tahun 2014, 11 perseroan mempunyai EPS Negatif pada tahun 2017, dan 8 perseroan yang mempunyai EPS Negatif pada tahun 2018. Kenaikan jumlah perseroan yang mempunyai EPS negatif mempengaruhi penyusutan kesejahteraan kepada pemegang saham perseroan yang bersangkutan. Perihal tersebut disebabkan perseroan tidak mempunyai keahlian yang layak untuk 
membagikan keuntungan pada tiap lembar saham yang ada.

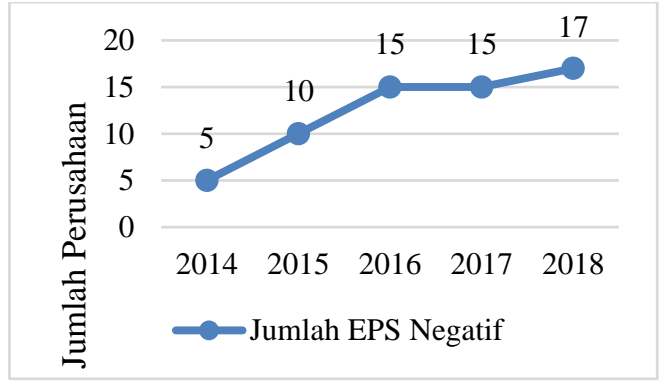

Gambar 2: Earning Per Share (EPS)

Perseroan Pertambangan Malaysia

Gambar 2 memvisualisasikan jika jumlah perseroan pertambangan di Malaysia yang mempunyai EPS negatif cenderung melonjak. Dari 32 perseroan yang tercatat di Bursa Malaysia, tahun 2018 perseroan yang mempunyai EPS negatif sebanyak 17 perseroan, sedangkan 15 perseroan mempunyai EPS negatif pada tahun 2016, 15 perseroan mempunyai EPS Negatif pada tahun 2016 serta 2017, 10 perseroan mempunyai EPS Negatif pada tahun 2015, dan 5 perseroan yang mempunyai EPS Negatif pada tahun 2014. Kenaikan jumlah perseroan yang mempunyai EPS negatif dapat mempengaruhi penyusutan kesejahteraan kepada pemegang saham perseroan yang bersangkutan. Perihal tersebut disebabkan industri tidak mempunyai keahlian yang layak untuk membagikan keuntungan pada tiap lembar saham yang ada.

\section{KAJIAN LITERATUR}

\section{Signalling Theory}

Signalling theory ialah teori yang mangulas tentang naik turunnya harga di pasar semacam hargasaham, obligasi serta yang lainnya. Sehingga hendak berikan pengaruh pada keputusan investor (Fahmi, 2014:22). Signalling theory menekankan bahwa berartinya keputusan investasi pihak di luar perseroan terpaut data yang dikeluarkan perseroan. Data yang dikeluarkan perseroan bisa berbentuk laporan tahunan. Data dari laporan tahunan memaparkan mengenai laporan keuangan serta non- keuangan. Dengan terdapatnya laporan tahunan diyakini bisa memengauruhi keputusan investasi pihak di luar perseroan dan berguna untuk di mengerti oleh pihak dalam ataupun pihak luar.

\section{Agency Theory}

Menurut Fathonah (2016) teori agensi ialah sebuah kontrak antara pihak manajer dengan pemilik perseroan, dimana pihak manajer diberi kepercayaan oleh pemilik perseroan guna mengelola perseroan sesuai kontrak yang sudah disepakati antara dua belah pihak. Teori agensi ini memicu konflik dari adanya pemisahan kepemilikan serta pengelolaan perseroan. Oleh sebabnya, teori agensi menekankan pentingnya pemilik perseroan mempercayakan pengelolaan perseroan kepada pekerja professional yang 


\section{Nominal: Barometer Riset Akuntansi dan Manajemen \\ P-ISSN: 2303-2065 E-ISSN: 2502-5430 \\ Volume 10 No 2 (2021)}

mempunyai pengalaman lebih dalam melaksanakan bisnis hariannya. Tujuan dari pemisahan pengelolaan dari kepemilikan perseroan, yaitu supaya pemilik perseroan mendapatkan keuntungan maksimal dengan biaya paling efisien (Sutedi, 2011:13).

\section{Financial Distress}

Menurut Platt dan Platt (2002) financial distress ialah proses turunnya posisi keuangan perseroan yang terjadi sebelum perseroan bangkrut maupun mengalami kondisi likuidasi. Apabila perseroan mengalami masalah dalam likuiditas, maka kemungkinkan perseroan tersebut memasuki awal masa kesulitan keuangan, apabila situasi tersebuttidak segera diatasi,maka dapat mengakibatkan kebangkrutan usaha (Fahmi, 2014:169). Kesulitan keuangan dapat dialami setiap perseroan, baik perseroan yang berskala besar ataupun berskala kecil karena faktor yang menyebabkan financial distress dapat berasal dari internal ataupun eksternal perseroan.

\section{Dampak Liquidity Pada Financial Distress}

Liquidity ratio ialah rasio yang memvisualisasikan daya perseroan dalam melunasi liabilitas jangka pendeknya yang segerajatuh tempo. Likuiditas pada studi ini memakai proksi current ratio. Currentratio ialah salah satu indikator guna mengukur rasio likuiditas yang membandingkan current assets serta current liabilities. Perseroan yang sanggup melunasi liabilitas jangka pendeknya yang segerajatuh tempo padatepat waktu, dapat dikatakan bahwa perseroan tersebut termasuk perseroan yang berada dalam kondisi likuid. Agar perseroan tetap berada dalam kondisi likuid, perseroan harus mempunyai tingkat ketersediaan aset lancar yang mudah dijadikan kas lebih besar dibanding hutang lancar karena dianggap mempunyai kemampuan untuk melunasi hutang lancar yang segera jatuh tempo sehingga kecil kemungkinan perseroan untuk mengalami financial distress. Ini berarti, tingkat likuiditas yang tinggi mampu menurunkan peluang perseroan mengalami financial distress.

H1 : Terdapat dampak negatif serta signifikan antara likuiditas pada financialdistress.

\section{Dampak Leverage Pada Financial Distress}

Leverage ratio ialah ratio yang memvisualisasikan daya perseroan dalam penggunaan sumber dana yang dibayari liabilitas. Dalam studi ini leverage ratio memakai proksi debt to asset ratio. Perseroan yang mempunyai jumlah hutang yang besar akan tetapi tidak didukung oleh kemampuan perseroan untuk menghasilkan jumlah laba yang tinggi akan memicu perseroan kedalam situasi sulit untuk memenuhi beban hutang kepada kreditur saat jatuh tempo, sehingga kemungkinan perseroan mengalami financial distress semakin besar. Ini berarti, tingkat leverage yang tinggi mampu menaikkan 


\section{Nominal: Barometer Riset Akuntansi dan Manajemen \\ P-ISSN: 2303-2065 E-ISSN: 2502-5430 \\ Volume 10 No 2 (2021)}

kemungkinan perseroan mengalami financial distress.

H2 : Terdapat dampak positif serta signifikan antara leverage pada financial distress.

\section{Dampak Operating Capacity Pada} Financial Distress

Operatingcapacity atau ratio aktivitas ialah rasio yang dipakai untuk menghitung sejauh mana efektivitas dan efisiensi perseroan dalam memakai aktiva yang dimilikinya. Indikator yang dipakai dalam studi ini ialahtotal asset turnover yakni hasil antara total penjualan dengan total aset. Tingkat total asset tunover yang tinggi menggambarkan perputaran aset yang dimiliki perseroan efektif dan efisien dalam melaksanakan operasional penjualanan sehingga menciptakan jumlah laba yang optimal. Ketika penjualan tinggi maka perseroan akan mampu melunasi semua bebannya, sehingga perseroan terhindar dari kerugian. Maka tingkat operating capacity yang tinggi dapat menekan kemungkinan perseroan mengalami financial distress.

H3 : Terdapat dampak negatif serta signifikan antara operating capacity pada financial distress.

\section{Dampak Institutional Ownership Pada}

\section{Financial Distress}

Institutional ownership ialah sejumlah saham perseroan yang dimiliki pihak institusi. Institutional ownership mempunyai kemampuan guna mengendalikan pihak manajemen lewat proses monitoring yang efektif. Pada studi ini institutional ownership diukur dengan membagi antara jumlah saham yang dimiliki oleh institusi denganjumlah saham yang beredar. Tingginya tingkat kepemillikan institusional mampu meningkatkan pengawasan lebih maksimal. Hal ini dapat meminimalisisir tingkat kecurangan, dan tindakan yang dapat merugikan perseroan yang mungkin dilakukan oleh manajer perseroan. Sehingga perseroan lebih efektif dan efisien untuk melaksanakan proses monitoring yang lebih optimal dan membuat kemungkinan perusahaaan mengalami financial distress semakin rendah.

H4 : Terdapat dampak negatif serta signifikan antara institutional ownership pada financial distress.

\section{Dampak Managerial Ownership Pada Financial Distress}

Managerial ownership ialah sejumlah saham yang dimiliki oleh pihak manajemen dalam perseroan. Pada studi ini managerial ownership diukur dengan membagi antara jumlah saham yang dimiliki pihak manajemen pada jumlah saham yangberedar. Semakin besar managerial ownership dalam perseroan maka pihak manajemen dapat lebih maksimal untuk meningkatkan kinerja perseroan karena pihak manajemen mempunyai tanggung jawab terhadap 


\section{Nominal: Barometer Riset Akuntansi dan Manajemen}

P-ISSN: 2303-2065 E-ISSN: 2502-5430

Volume 10 No 2 (2021)

kepentingan pemegang saham lainnya. Serta pengawasan pada pihak manajemen perseroan terhadap kebijakan yang akan ditetapkan mampu mengurangi tindakan kecurangan dari pihak manajemen, sehingga perseroan sanggup menekan peluang terjadinya financial distress.

H5 : Terdapat dampak negatif serta signifikan antara managerial ownership pada financial distress.

\section{Dampak Independent Comissioner Pada}

\section{Financial Distress}

Independent comissioner ialah personel dewan komisaris yang tidak tergabung bersama manajemen, personel dewan komisaris yang lain serta pemilik saham pengendali, juga terbebas dari ikatan bisnis ataupun ikatan yang lain yang mampu memberi pengaruh kepada kemampuannya guna bertindak independent demi keperluan perseroan. Proporsi komisaris independen yang besar akan menambah keterampilan pengawasan dewan komisaris independen terhadap pengambilan keputusan manajemen supaya keputusan yang diambil tepat serta mengawasi kinerja dewan direksi dalam perihal mengendalikan mengenai permasalahan financial supaya tidak mengalami sesuatu tindakan yang bisa merugikan perseroan. Sehingga proporsi independent comissioner yang besar akan menekan peluang perseroan mengalami financial distress.
H6 : Terdapat dampak negatif serta signifikan antara independent iomissioner pada financialdistress.

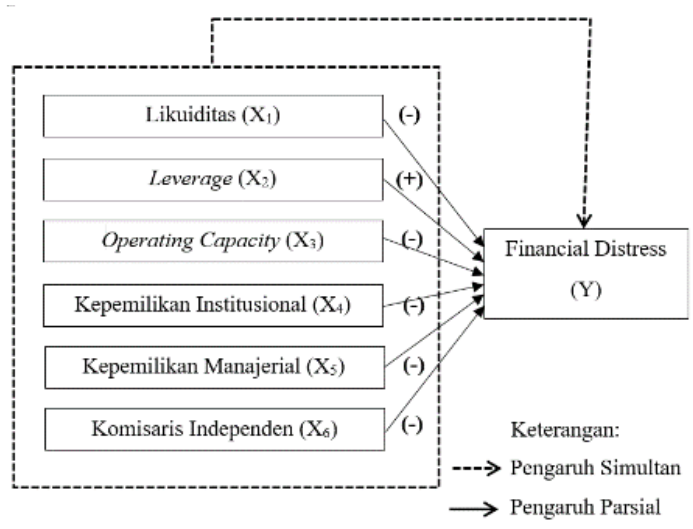

Gambar 2: Kerangka Pemikiran

\section{METODE PENELITIAN}

Studi ini memakai penelitian deskriptif yang mempunyai tujuan guna mengenali nilai tiap- tiap variabel, dari satu variabel ataupun lebih yang bersifat independen tanpa mewujudkan ikatan ataupun perbandingan variabel yang lainnya (Sujarweni, 2015:49). Tujuan dari studi ini yakni guna mengenali dampak dari liquidity, leverage, operatingcacpacity, institutional ownership, managerial ownership, independent comissioner padafinancial distress.

\section{Populasi dan Sampel}

Populasi yaitu area penyamarataan yang terdiri berdasarkan objek ataupunsubjek yang mempunyai mutu serta ciri khusus yang diresmikan oleh riset guna dipahami serta mengambil keputusan (Sugiyono, 2018:80). Populasi pada studi ini yakni perseroan sektor pertambangan yang tercatat di 
BursaEfek Indonesia serta Bursa Malaysia tahun 2014-2018.

Tabel 1: Kriteria Pemilihan Sampel

\begin{tabular}{|c|c|c|}
\hline \multicolumn{3}{|c|}{ Sampel Penelitian di Indonesia } \\
\hline No. & Kriteria & Total \\
\hline 1. & $\begin{array}{l}\text { Perseoran Pertambangan } \\
\text { yang tercatat di BursaEfek } \\
\text { Indonesia pada tahun2014- } \\
2018 .\end{array}$ & 47 \\
\hline 2. & $\begin{array}{l}\text { Perseoran Pertambangan } \\
\text { yang tidak konsisten } \\
\text { mengunggah laporan tahunan } \\
\text { di BursaEfek Indonesia pada } \\
\text { tahun2014-2018. }\end{array}$ & (8) \\
\hline 3. & $\begin{array}{l}\text { Perseoran Pertambangan } \\
\text { yang memakai mata uang } \\
\text { dollar pada laporan tahunan } \\
\text { dan terdaftar di BursaEfek } \\
\text { Indonesia pada tahun2014- } \\
2018 \text {. }\end{array}$ & $(27)$ \\
\hline \multicolumn{2}{|c|}{$\begin{array}{l}\text { Jumlah Perseoran yang terpilih } \\
\text { menjadi sampel }\end{array}$} & 12 \\
\hline \multicolumn{3}{|c|}{ Sampel Penelitian di Malaysia } \\
\hline No. & Kriteria & Total \\
\hline 1. & $\begin{array}{l}\text { Perseoran Pertambangan } \\
\text { yang tercatat di Bursa } \\
\text { Malaysia tahun2014-2018. }\end{array}$ & 32 \\
\hline 2. & $\begin{array}{l}\text { Perseoran Pertambangan } \\
\text { yang tidak konsisten } \\
\text { mengunggah laporan tahunan } \\
\text { di Bursa Malaysia pada } \\
\text { tahun2014-2018. }\end{array}$ & (10) \\
\hline 3. & $\begin{array}{l}\text { Perseoran Pertambangan } \\
\text { yang memakai mata uang } \\
\text { dollar pada laporan tahunan } \\
\text { dan terdaftar di Bursa } \\
\text { Malaysia pada tahun2014- } \\
\text { 2018. }\end{array}$ & (0) \\
\hline \multicolumn{2}{|c|}{$\begin{array}{l}\text { Jumlah Perseoran yang terpilih } \\
\text { menjadi sampel }\end{array}$} & 22 \\
\hline
\end{tabular}

Sampel ialah bagian yang terdiri dari jumlah serta karakteristik pada suatu populasi yang bersifat representatif atau dapat mewakili populasi yang diambil dalam penelitian (Sugiyono, 2018:81). Studi ini memakai sampel pada perseroan sektor pertambangan yang tercatat di BursaEfek Indonesia serta Bursa Malaysia tahun 20142018.

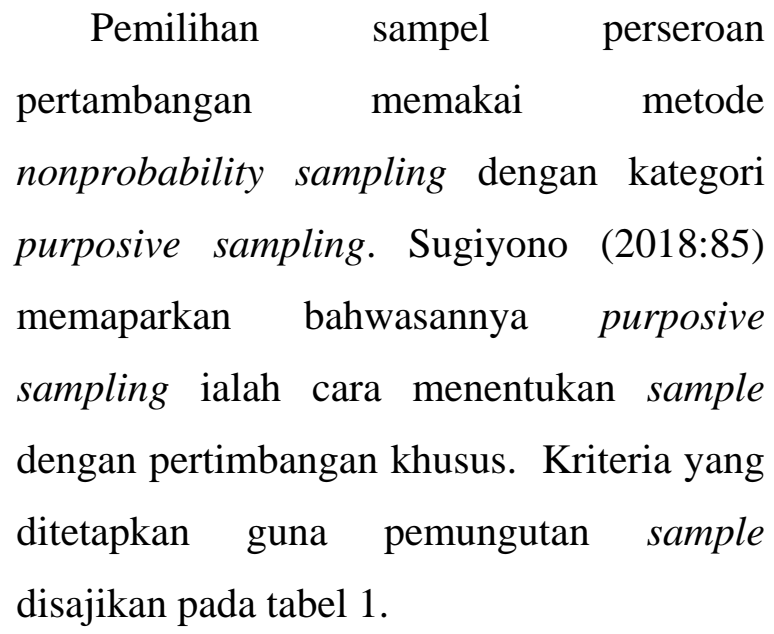

\section{Metode Pengumpullan Data}

Sumber data yang dipakai pada studi ini ialah data sekunder. Metode pengumpulan informasi dalam studi kali ini yakni dokumentasi, ialah dengan memakai informasi sekunder berbentuk laporan tahunan Perseroan Pertambangan yang terdaftar di BursaEfek Indonesia serta Bursa Malaysia tahun 2014- 2018. Laporan tahunan yang digunakan dalam studi kali ini didapat dari situs resmi BursaEfek Indonesia ialah (idx.co.id) serta situs resmi Bursa Malaysia (bursamalaysia.com) dan lewat situs resmi perseroan yang terdaftar pada perseroan sektor pertambangan.

\section{Operasionalisasi Variabel}

\section{Variabel Terikat}

Variabel terikat yaitu variabel yang mnerima pengaruh atau yang menjadi akibat dari variabel bebas (Sugiyono, 2018:39). 
Variabel terikat pada studi ini yakni Financial Distress. Financialdistress diukur memakai variabel dummy dengan melihat nilai Earning Per Share (EPS) pada laporan tahunan perseroan. Apabila perseroan mempunyai nilai EPS minus diberi nilai 1 . Sedangkan, perseroan yang mempunyai nilai EPS plus diberi nilai 0 .

\section{Variabel Bebas}

Variabel bebas yakni variabel yang memberikan pengaruh atau yang peran sebab munculnya variabel terikat. Variabel bebasyang dipakai dalam studi ini yaitu Liquidity, Leverage, OperatingCapacity, Institutional Ownership, Managerial Ownership, Independent Commissioner.

\section{a. Liquidity}

Liquidity diukur memakai currentratio (CR). Currentratio ialah rasio guna mengukur kemampuan perseroan dalam melunasi currentliabilities yang segera jatuh tempo dengan memakai currentasset yang dimiliki (Hery, 2016:152). Rumus untuk current ratio yaitu sebagai berikut.

$$
C R=\frac{\text { Current Assets }}{\text { Current Liabilities }}
$$

\section{b. Leverage}

Leverage diukur memakai debt to asset ratio (DAR) ialah ratio yang memvisualisasikan kemampuan perseroan dalam melunasi liabilitasnya. Ratio ini membandingkan antara total liabilities dengan total assets yang dimiliki perseroan memperlihatkan sejauh apa dana yang dipinjam telah dipakai guna membeliaset (Fahmi, 2014:127). Rumus untuk debt to asset ratio yaitu sebagai berikut.

$$
D A R=\frac{\text { Total Liabilities }}{\text { Total Assets }}
$$

\section{c. Operating Capacity}

Operatingcapacity diukur memakai total assetturnover (TATO). Menurut Hery (2016:166) totalasset turnover ialah ratio yang dipakai untuk mengukur efektifnya total assets yang dipunyai perseroan dalam menghasilkan sales, atau dengan demikian guna mengukur jumlah yang mampu dihasilkan dari setiap rupiahdana yang tertanam dalam total assets. Rumus guna total assetturnover yaitu sebagai berikut.

$$
\text { TATO }=\frac{\text { Sales }}{\text { Total Assets }}
$$

\section{d. Institutional Ownership}

Kepemilikaninstitusional (KI) diukur dengan membagi antara jumlahsaham yang dipunyai institusi dengan jumlahsaham yang beredar. Menurut Fathonah (2016) institutional ownership mempunyai keahlian guna mengatur pihak manajemen lewat prosesmonitoring secara efektif. Perihal ini sebab kepemilikan saham mewakilkan suatu sumberkekuasaan yang bisa dipakai guna menunjang ataupun kebalikannya terhadap kehadiran manajemen, sehingga dengan institutional ownership, biaya agensi sanggup diminimalisir. Institutional 
ownership menurut (Udin et al., 2017) dinyatakan sebagai berikut.

$$
\mathrm{KI}=\frac{\text { Saham yangdimiliki institusional }}{\text { Jumlah saham yang beredar }}
$$

\section{e. Managerial Ownership}

Managerial ownership (KM) dihitung dengan membagi antara jumlahsaham yang dipunyai manajer dengan jumlah sahamyang beredar. Menurut Hanafi (2014:75) managerial ownership ialah besarnya kepemilikan saham yang dipunyai pihak manajemen ataupun dengan demikian manajer pula selaku pemilik saham, yang secaraaktif turut dalam pemungutan keputusan dan juga turut menerima dampak langsung makna dari keputusan yang telah diambil serta menerima akibat bila terdapat kerugian yang muncul sebagai konsekuensi dari pemungutan keputusan yang salah. Rumus managerial ownership yaitu sebagai berikut.

$$
\mathrm{KM}=\frac{\text { Saham yangdimiliki manajerial }}{\text { Jumlah sahamyang beredar }}
$$

\section{f. Independent Comissioner}

Kommisaris independen (KIN) dihitung dengan membandingkan jumlah dewan komisarisindependen dengan jumlah anggota dewan. Komisarisindependen ialah anggota dewankomisaris yang tidak tergabung bersama manajemen, anggotadewan komisaris yang lain serta pemilik saham pengendali, dan juga leluasa dari ikatan bisnis ataupun ikatan lain yang mampu memberi pengaruh pada kemampuannya guna berperan independent ataupun bertindak sekadar demi keperluan perseroan (KNKG, 2006:13)

$$
\text { KIN }=\frac{\text { Jumlah KomisarisIndependen }}{\text { Jumlah DewanKomisaris }}
$$

\section{Metode Olah Data}

Teknik olah data pada studi ini memakai metode logistic regression lewat aplikasi SPSS 25 .

\section{HASIL PENELITIAN DAN \\ PEMBAHASAN}

\section{Analisis Statistik Deskriptif}

Statistik deskriptif ialah statistik yang dipakai guna menganalisa laporan dengan mendeskripsikan ataupun memvisualisasikan informasi yang sudah dikumpulkan sebagaimana adanya tanpa mempunyai maksud mengambil konklusi yang telah berlaku secara umum (Sugiyono, 2018:147). Studi ini bertujuan buat mengenali pengaruh variabel independen yakni Liquidity, Leverage, OperatingCapacity, Institutional Ownership, Managerial Ownership, serta Independent Commissioner terhadap variabel dependen yakni financial distress. Jumlah sampel pada perseroan yang tercata di Bursa EfekIndonesia sebanyak 12 perseroan pertambangan dengan rentang waktu riset selama 5 tahun sehingga diperoleh sampel sebanyak 60 sampel, serta jumlah sampel pada perseroan yang tercatat di Bursa 
Nominal: Barometer Riset Akuntansi dan Manajemen

P-ISSN: 2303-2065 E-ISSN: 2502-5430

Volume 10 No 2 (2021)

Malaysia sebanyak 22 perseroan

Kepemilikan Institusional

(KI)

pertambangan dengan rentang waktu riset

mempunyai angka rerata yakni 0,486 > 0,322 selama 5 tahun sehingga diperoleh sampel sebanyak 110 sampel.

Tabel 2: Hasil Analisis Descriptive Statistic

\begin{tabular}{|c|c|c|c|c|c|}
\hline IDN & $\mathbf{N}$ & MIN & $M A X$ & MEAN & $\begin{array}{l}\text { Std. } \\
\text { Dev }\end{array}$ \\
\hline CR & 60 & .213 & 111,312 & 4,243 & $\begin{array}{r}14.50 \\
9\end{array}$ \\
\hline DAR & 60 & .040 & 1.068 & .466 & .177 \\
\hline TATO & 60 & 0 & 1.463 & .433 & .436 \\
\hline KI & 60 & 0 & .973 & .486 & .322 \\
\hline KM & 60 & 0 & .495 & .067 & .151 \\
\hline KIN & 60 & .200 & .750 & .387 & .097 \\
\hline Valid $N$ & 60 & & & & \\
\hline MYS & $\mathbf{N}$ & $M I N$ & $M A X$ & MEAN & $\begin{array}{l}\text { Std. } \\
\text { Dev }\end{array}$ \\
\hline$\overline{\mathrm{CR}}$ & 110 & .063 & 5.126 & 1.336 & .837 \\
\hline DAR & 110 & .103 & 1.460 & .546 & .205 \\
\hline TATO & 110 & .003 & 5.073 & .680 & .972 \\
\hline KI & 110 & .158 & .982 & .630 & .211 \\
\hline KM & 110 & 0 & 0349 & .054 & .088 \\
\hline KIN & 110 & .142 & .750 & .496 & .122 \\
\hline Valid $N$ & 110 & & & & \\
\hline
\end{tabular}

Sesuai dengan tabel 2 hasil uji deskriptif perseroan sektor pertambangan Indonesia memperlihatkan bahwa likuiditas (CR) mempunyai angka rerata yakni 4,243 < 14,509 dari angka standard deviation, artinya data dari variabel likuiditas bervariasi serta tidak berkelompok.

Leverage (DAR) mempunyai angka rerata yakni $0,466>0,117$ dari angka standard deviation, artinya data dari variabel leverage tidak bervariasi serta berkelompok.

Operating Capacity (TATO) mempunyai angka rerata yakni 0,433<0,436 dari angka standard deviation, artinya data dari variabel operating capacity bervariasi serta tidak berkelompok.

dari angka standard deviation, artinya data dari variabel kepemilikan institusional tidak bervariasi serta berkelompok.

Kepemilikan Manajerial

(KM) mempunyai angka rerata yakni $0,067<0,151$ dari angka standard deviation, artinya data dari variabel kepemilikan manajerial bervariasi serta tidak berkelompok.

Komisaris Independen

(KIN) mempunyai angka rerata yakni 0,387 > 0,097 dari angka standard deviation, artinya data dari variabel komisaris independen tidak bervariasi serta berkelompok.

Sedangkan pada perseroan sektor pertambangan Malaysia memperlihatkan bahwa likuiditas (CR) mempunyai angka rerata yakni $1,336>0,837$ dari angka standard deviation, artinya data dari variabel likuiditas tidak bervariasi serta berkelompok.

Leverage (DAR) mempunyai angka rerata yakni $0,546>0,205$ dari angka standard deviation, artinya data dari variabel leverage tidak bervariasi serta berkelompok.

Operating Capacity (TATO) mempunyai angka rerata yakni $0,680<0,972$ dari angka standard deviation, artinya data dari variabel operating capacity bervariasi serta tidak berkelompok.

Kepemilikan Institusional

(KI) mempunyai angka rerata yakni 0,630>0,211 dari angka standard deviation, artinya data 


\section{Nominal: Barometer Riset Akuntansi dan Manajemen}

P-ISSN: 2303-2065 E-ISSN: 2502-5430

Volume 10 No 2 (2021)

dari variabel kepemilikan institusional tidak bervariasi serta berkelompok.

Kepemilikan Manajerial

(KM)

mempunyai angka rerata yakni $0,054<0,088$ dari angka standard deviation, artinya data dari variabel kepemilikan manajerial bervariasi serta tidak berkelompok.

Komisaris Independen

(KIN)

mempunyai angka rerata yakni $0,496>0,122$ dari angka standard deviation, artinya data dari variabel komisaris independen tidak bervariasi serta berkelompok.

\section{Uji Semua Model}

Pengujian ini dilakukan guna memutusukan bila variabelbebas dimaukkan ke dalam model apakah secara signifikan mampu memperbaiki data (Ghozali, 2018:332).

Tabel 3: Overall ModelFit Test

\begin{tabular}{cc}
\hline \multicolumn{2}{c}{ Indonesia } \\
\hline $\begin{array}{c}-2 \text { LogLBlock Number } \\
=0\end{array}$ & MempunyaiNilai \\
80.762 \\
-2 LogLBlock Number & MempunyaiNilai \\
$=1$ & 47.492 \\
\hline \multicolumn{2}{c}{ Malaysia } \\
\hline-2 LogLBlock Number & MempunyaiNilai \\
$=0$ & 151.181 \\
-2 LogLBlock Number & MempunyaiNilai \\
$=1$ & 118.876 \\
\hline
\end{tabular}

Pada tabel 3 hasil overall model fit test sektor pertambangan Indonesia dapat diketahui bahwa nilai awal -2Loglikelihood (BlockNumber $=0)$ sejumlah 80,762 serta 2 Log likelihood (Block Number $=1$ ) sejumlah 80,892. Perihal ini menampilkan bahwa nilai -2Loglikelihood (BlockNumber $=$
1) lebih rendah dibanding nilai $-2 \log$ likelihood(Block Number $=$ 0) dengan penyusutan sebesar 33,270 sehingga bisa disimpulkan jika modelfit dengan data serta mampu dibuktikan jika variabel likuiditas, leverage, operatingcapacity, institutional ownership, managerial ownership, serta independent comissionerssecara signifikan mampu memperbaiki model fit. Sedangkan pada test sektor pertambangan Indonesia dapat diketahui bahwa nilai awal 2Loglikelihood (Block Number $=0$ ) sejumlah 151,181 serta -2Loglikelihood (Block Number $=1)$ sejumlah 118,876 . Perihal ini menampilkan bahwa nilai -2Loglikelihood (BlockNumber $=1)$ lebih rendah dibanding dengan nilai -2Loglikelihood (BlockNumber= 0) dengan penyusutan sebesar 32,305 sehingga bisa disimpulkan jika modelfit dengan data serta mampu dibuktikan jika variabel likuiditas, leverage, operatingcapacity, institutional ownership, managerial ownership, serta independent comissionerssecara signifikan mampu memperbaiki model fit.

\section{Uji Kelayakan Model}

Pengambilan keputusan dilakukan apabila probabilitas $(\mathrm{sig})>0,05$ sehinggaHo diterima sebab model sesuai serta cocok dengandata, sebaliknya apabila probabilitas $($ sig $)<0,05$ sehinggaH $H_{0}$ ditolak serta menampilkan jika model tidak bisa diapakai sebab adanya perbedaan yangsignifikan 
antara modeldengan nilai data sehingga model tidak bisa memprediksi nilaidatanya (Ghozali, 2018:333).

Tabel 4: Hosmerand Lameshow Test

\begin{tabular}{lcrrr}
\hline \multicolumn{4}{c}{ Indonesia } \\
\hline Step & Chi-square & $d f$ & Sig. \\
\hline 1 & .976 & 8 & .998 \\
\hline \multicolumn{4}{c}{ Malaysia } \\
\hline Step & Chi-square & $d f$ & Sig. \\
\hline 1 & 6.492 & 8 & .592 \\
\hline
\end{tabular}

Pada tabel 4 hasil Hosmer and Lameshow Test pada sektor pertambangan Indonesia mempunyai nilai chi-square sejumlah 0,976 dengan angka signifikansi 0,998 yang memperlihatkan bahwa nilai chi-square lebih besardari 0,05 sehingga hipotesis diterima atau tidak dapat ditolak, sehingga model dapat dikatakan fit. Sedangkan pada sektor pertambangan Malaysia mempunyai nilai chi-square sejumlah 6,492 dengan angka signifikansi 0,592 yang memperlihatkan bahwa angka chi-square lebihbesar dari 0,05 saehingga hipotesis diterima sehinggamodel dapat dikatakan fit.

\section{Uji Koefisien Determinasi}

Menguji koefisiensi determinasi dipakai guna mengukur besarnya variabel bebas berkontribusi memberi dampak pada variabel terikatnya. Angka uji koefisien determinasi terletak diantara rentang angka 0 serta 1. Apabila angka koefisien determinasi kecil, berarti kapasitas variabel bebas dalam memaparkan variabel terikatnya amat terpaku. Namun, bila angka koefisien determinasi mencapai angka 1, artinya variabel bebas telah mampu membagikan seluruh data yang diperlukan guna memprediksi variabel terikat (Ghozali, 2018:97).

Tabel 5: Model Summary

\begin{tabular}{lccc}
\hline \multicolumn{4}{c}{ Indonesia } \\
\hline \multirow{2}{*}{ Step } & $\begin{array}{c}\text {-2Log } \\
\text { likehood }\end{array}$ & $\begin{array}{c}\text { Cox\& Snell } \\
R \text { Square }\end{array}$ & $\begin{array}{c}\text { Nagellkerke } \\
R \text { Square }\end{array}$ \\
\hline 1 & 35.267 & .532 & .719 \\
\hline \multicolumn{4}{c}{ Malaysia } \\
\hline \multirow{2}{*}{ Step } & $\begin{array}{c}-2 \text { Log } \\
\text { likehood }\end{array}$ & $\begin{array}{c}\text { Cox\& Snell } \\
R \text { Square }\end{array}$ & $\begin{array}{c}\text { Nagellkerke } \\
R \text { Square }\end{array}$ \\
\hline 1 & 115.914 & .274 & .367 \\
\hline
\end{tabular}

Pada tabel 4 memperlihatkan hasil Nagelkerke's $R$ Square pada sektor pertambangan Indonesia sejumlah 0,719 atau sejumlah $71,9 \%$ yang mempunyai makna bahwa variabel likuiditas, leverage dan operating capacity, institutionalownership, managerialownership, serta independent comissionermampu memaparkan variasi dari financial distress dan selebihnya sejumlah $28,1 \%$ disebabkan oleh variabel lain di luar studi ini. Sedangkan pada sektor pertambangan Malaysia sejumlah 0,367 atau sejumlah $36,7 \%$ yang mempunyai makna bahwa variabel likuiditas, leverage dan operating capacity, institutionalownership, managerialownership, serta independent comissionermampu memaparkan variasi dari financial distress dan selebihnya sebesar $63,3 \%$ disebabkan oleh variabel lain di luar studi ini. 


\section{Hasil Pengujian Simultan}

Pada analisis regresi logistik, uji signifikansi simultan dilihat pada tabel OmnibusTest ofModelCoefficients. Jika angka sig. $<0.05$ sehinggaH 0 ditolak serta $\mathrm{Ha}$ diterima, artinya variabel bebas mempunyai dampak secarasimultan pada variabel terikat. Tetapi bila angka sig. $>0.05$ makaH $_{0}$ diterima dan Ha ditolak, sehingga variabel bebas secarasimultan tidak mempunyai dampak pada variabelterikat (Ghozali, 2018:98).

Tabel 6: OmnibusTest ofModelCoefficients

\begin{tabular}{ccrcc}
\hline \multicolumn{2}{c}{ Indonesia } & Chi-square & \multicolumn{1}{c}{ df } & Sig. \\
\hline Step 1 & Step & 45.494 & 6 & .000 \\
& Block & 45.494 & 6 & .000 \\
& Model & 45.494 & 6 & .000 \\
\hline \multicolumn{2}{c}{ Malaysia } & Chi-square & df & Sig. \\
\hline Step 1 & Step & 35.267 & 6 & .000 \\
& Block & 35.267 & 6 & .000 \\
& Model & 35.267 & 6 & .000 \\
\hline
\end{tabular}

Pada tabel 6 terlihat bahwa sektor pertambangan Indonesia mempunyai chisquare dengan nilai 45,494 serta $d f$ sebesar 6 . Tingkat signifikansi yang diperoleh senilai 0,000 yang memiliki arti bahwa( $p$-value < 0,05). SehinggaHo ditolak atauHa diterima yang mempunyai makna bahwa secara simultan variabel bebas yakni liquidity, leverage serta operating capacity, institutional ownership, managerial ownership, serta independent comissioner mempunyai dampak pada variabel terikat yakni financial distress. Sedangkan pada sektor pertambangan Malaysia mempunyai chi-square dengan nilai 35,267 serta $d f$ sebesar 6. Tingkat signifikansi yang diperoleh senilai 0,000 yang memiliki arti bahwa $(p$-value $<0,05)$. SehinggaH ${ }_{0}$ ditolak atauHa diterima yang mempunyai makna bahwa secara simultan variabel bebas yakni liquidity, leverage dan operatingcapacity, institutional ownership, managerial ownership, serta independent comissioner mempunyai dampak pada variabel terikat yakni financial distress.

\section{Hasil Pengujian Parsial}

Uji parsial dilaksanakan guna mengenali dampak setiap variabel bebas pada variabel terikat. Pada analisis regresi logistik, uji signifikansi dapat dilihat pada tabel variable in theequation. Pengujian ini dilakukan dengan menguji koefisien regresi dengan membandingkan antara nilai signifikansi dengan tingkatan signifikansi $(\alpha)$ 5\%.

Tabel 7: Variable in theEquation

\begin{tabular}{|c|c|c|c|c|c|c|}
\hline IDN & B & S.E & $\begin{array}{c}W a \\
l d\end{array}$ & $d f$ & Sig. & $\begin{array}{c}E \operatorname{Exp}( \\
B)\end{array}$ \\
\hline CR & .114 & .135 & .709 & 1 & $\begin{array}{r}.40 \\
0\end{array}$ & $\begin{array}{r}1.12 \\
1\end{array}$ \\
\hline DAR & 6.570 & 4.244 & $\begin{array}{r}2.39 \\
7\end{array}$ & 1 & $\begin{array}{r}.12 \\
2\end{array}$ & $\begin{array}{r}713,2 \\
98\end{array}$ \\
\hline $\begin{array}{l}\text { TAT } \\
\mathrm{O}\end{array}$ & $\begin{array}{r}- \\
-\end{array}$ & 5.052 & $\begin{array}{r}6.59 \\
0\end{array}$ & 1 & $\begin{array}{r}.01 \\
0\end{array}$ & .000 \\
\hline KI & -2.663 & 2.053 & $\begin{array}{r}1.68 \\
3\end{array}$ & 1 & $\begin{array}{r}.19 \\
5\end{array}$ & .070 \\
\hline KM & 24.611 & $\begin{array}{r}24.08 \\
3\end{array}$ & $\begin{array}{r}1.04 \\
4\end{array}$ & 1 & $\begin{array}{r}.30 \\
7\end{array}$ & \\
\hline KIN & -3.002 & $\begin{array}{r}3.85 \\
5\end{array}$ & $\begin{array}{r}.60 \\
7\end{array}$ & 1 & $\begin{array}{r}.43 \\
6\end{array}$ & .050 \\
\hline $\begin{array}{l}\text { Cons } \\
\text { tant }\end{array}$ & 1.795 & $\begin{array}{r}2.82 \\
9\end{array}$ & $\begin{array}{r}.40 \\
3\end{array}$ & 1 & $\begin{array}{r}.52 \\
6\end{array}$ & $\begin{array}{r}6.02 \\
2\end{array}$ \\
\hline
\end{tabular}




\begin{tabular}{|c|c|c|c|c|c|c|}
\hline MYS & B & S.E & $\begin{array}{l}\text { Wa } \\
l d\end{array}$ & $d f$ & Sig. & $\begin{array}{c}E \operatorname{Exp}( \\
B)\end{array}$ \\
\hline $\mathrm{CR}$ & -1.337 & .508 & $\begin{array}{r}6.9 \\
17\end{array}$ & 1 & $\begin{array}{r}.00 \\
9\end{array}$ & .263 \\
\hline DAR & .287 & $\begin{array}{r}1.71 \\
1\end{array}$ & $\begin{array}{r}.02 \\
8\end{array}$ & 1 & $\begin{array}{r}.86 \\
7\end{array}$ & $\begin{array}{r}1.23 \\
2\end{array}$ \\
\hline $\begin{array}{l}\text { TAT } \\
\text { O }\end{array}$ & -.477 & .270 & $\begin{array}{r}3.1 \\
21\end{array}$ & 1 & $\begin{array}{r}.07 \\
7\end{array}$ & .621 \\
\hline KI & -1.746 & $\begin{array}{r}1.21 \\
7\end{array}$ & $\begin{array}{r}2.0 \\
58\end{array}$ & 1 & $\begin{array}{r}.15 \\
1\end{array}$ & .174 \\
\hline KM & -9.167 & $\begin{array}{r}3.62 \\
1\end{array}$ & $\begin{array}{r}6.4 \\
10\end{array}$ & 1 & $\begin{array}{r}.01 \\
1\end{array}$ & .000 \\
\hline KIN & -4.258 & $\begin{array}{r}2.05 \\
1\end{array}$ & $\begin{array}{r}4.3 \\
11\end{array}$ & 1 & $\begin{array}{r}.03 \\
8\end{array}$ & $\begin{array}{r}70.6 \\
93\end{array}$ \\
\hline $\begin{array}{l}\text { Cons } \\
\text { tant }\end{array}$ & 1.103 & $\begin{array}{r}1.83 \\
9 \\
\end{array}$ & $\begin{array}{r}.35 \\
9 \\
\end{array}$ & 1 & $\begin{array}{r}.54 \\
9 \\
\end{array}$ & $\begin{array}{r}3.01 \\
3 \\
\end{array}$ \\
\hline
\end{tabular}

Model Persamaan Logistik

$$
\begin{aligned}
L n=\frac{\text { FD }}{(1-\text { FD })}= & 1,795+0,114(\mathrm{CR})+6,570(\mathrm{DAR}) \\
& -12,970(\mathrm{TATO})-2,663(\mathrm{KI}) \\
& +24,611(\mathrm{KM})-3,002(\mathrm{KIN})
\end{aligned}
$$

\section{Pembahasan}

\section{Dampak Liquidity pada Financial Distress}

Uji logistic regression pada tabel 7 memperlihatkan variabel liquidity pada sektor pertambangan Indonesia mempunyai angka koefisiensi regresi sebesar 0,114 serta angka signifikansi sebesar $0,400<5 \%$ dari tingkat signifikansi $(\alpha)$, nilai ini memperlihatkan bahwa Ha1 ditolak atau $\mathrm{H}_{0} 1$ diterima. Hal ini memperlihatkan bahwa variabel likuiditas (CR) tidak mempunyai dampak pada financial distress pada perseroan sektor pertambangan Indonesia tahun 2014-2018. Dengan demikian, uji tersebut tidak selaras pada kerangka pemikiran yang telah dibuat yakni liquidity mempunyai pengaruh signifikan negatif terhadap financialdistress. Hasil studi tersebut tidak selaras bersama hasil studi Widhiari dan Merkusiwati (2015) juga Zhafirah dan Majidah (2019) yang memaparkan bahwa likuiditas memiliki dampak signifikan terhadap financial distress.

Sedangkan pada sektor pertambangan Malaysia mempunyai angka koefisiensi regresi sebesar $-1,337$ serta angka signifikansi sejumlah $0,009<5 \%$ dari tingkat signifikansi $(\alpha)$, nilai ini memperlihatkan bahwa Ha1 diterima atau $\mathrm{H}_{0} 1$ ditolak. Hal tersebut memperlihatkan bahwa variabel likuiditas (CR) mempunyai dampak secara signifikan negatif terhadap financial distress pada perseroan sektor pertambangan Malaysia tahun 2014-2018. Dengan demikian, uji tersebut selaras pada kerangka pemikiran yang telah dibuat yakni liquidity mempunyai pengaruh signifikan negatif terhadap financialdistress. Hasil studi tersebut selaras bersama hasil studi Widhiari dan Merkusiwati (2015) juga Zhafirah dan Majidah (2019) yang memaparkan bahwa likuiditas mempunyai dampak signifikan pada financial distress.

\section{Dampak Leverage pada Financial Distress}

Hasil uji logistic regression variabel leverage pada sektor pertambangan Indonesia mempunyai angka koefisiensi regresi sebesar 6,570 serta angka signifikansi sebesar $0,122<5 \%$ dari tingkat signifikansi $(\alpha)$, nilai ini memperlihatkan bahwa Ha1 


\section{Nominal: Barometer Riset Akuntansi dan Manajemen}

P-ISSN: 2303-2065 E-ISSN: 2502-5430

Volume 10 No 2 (2021)

ditolak atau $\mathrm{H}_{0} 1$ diterima. $\mathrm{Hal}$ ini memperlihatkan bahwa variabel leverage (DAR) tidak mempunyai dampak pada financial distress pada perseroan sektor pertambangan Indonesia tahun 2014-2018. Dengan demikian, uji tersebut tidak selaras pada kerangka pemikiran yang telah dibuat yakni leverage mempunyai pengaruh signifikan positif terhadap financialdistress. Hasil studi tersebut tidak selaras bersama hasil studi Susilowati et, al. (2019) serta Kristanti et, al. (2016) yang mengemukakan bahwa leverage memiliki dampak signifikan terhadap financial distress.

Sedangkan pada sektor pertambangan Malaysia mempunyai angka koefisiensi regresi sebesar 0,287 serta angka signifikansi sebesar $0,867<5 \%$ dari tingkat signifikansi $(\alpha)$, nilai ini memperlihatkan bahwa Ha1 ditolak atau $\mathrm{H}_{0} 1$ diterima. Hal ini memperlihatkan bahwa variabel leverage (DAR) tidak memiliki dampak pada financial distress pada perseroan sektor pertambangan Malaysia tahun 2014-2018. Dengan demikian, uji tersebut tidak selaras pada kerangka pemikiran yang telah dibuat yakni leverage mempunyai pengaruh signifikan positif terhadap financialdistress. Hasil studi tersebut tidak selaras bersama hasil studi Susilowati et, al. (2019) serta Kristanti et, al. (2016) yang mengemukakan bahwa leverage memiliki dampak signifikan pada financial distress.

\section{Dampak Operating Capacity pada}

\section{Financial Distress}

Hasil uji logistic regression pada variabel operating capacity sektor pertambangan Indonesia mempunyai angka koefisiensi regresi sebesar -12,970 serta angka signifikansi sebesar $0,010<5 \%$ dari tingkat signifikansi $(\alpha)$, nilai ini memperlihatkan bahwa Hal diterima atau $\mathrm{H}_{0} 1$ ditolak. Hal ini memperlihatkan bahwa variabel operating capacity (TATO) mempunyai pengaruh secara signifikan positif terhadapfinancial distress pada perseroan sektor pertambangan Indonesia tahun 2014-2018. Dengan demikian, uji tersebut selaras pada kerangka pemikiran yang telah dibuat yakni operating capacity mempunyai pengaruh signifikan negatif padafinancial distress. Hasil studi tersebut selaras bersama hasil studi Lisiantara dan Febrina (2018) juga Widhiari dan Merkusiwati (2015) yang mengemukakan bahwa operating capacity mempunyai dampak signifikan pada financial distress.

Sedangkan pada sektor pertambangan Malaysia mempunyai angka koefisiensi regresi sebesar $-0,447$ serta angka signifikansi sebesar $0,077<5 \%$ dari tingkat signifikansi $(\alpha)$, nilai ini memperlihatkan bahwa $\mathrm{Ha} 1$ ditolak atau $\mathrm{H}_{0} 1$ diterima. Hal ini memperlihatkan bahwa variabel operating capacity (TATO) tidak mempunyai dampak pada financialdistress pada perseroan sektor 


\section{Nominal: Barometer Riset Akuntansi dan Manajemen \\ P-ISSN: 2303-2065 E-ISSN: 2502-5430 \\ Volume 10 No 2 (2021)}

pertambangan Malaysia tahun 2014-2018. Dengan demikian, uji tersebut tidak selaras pada kerangka pemikiran yang telah dibuat yakni operating capacity mempunyai pengaruh signifikan negatif padafinancial distress. Hasil studi tersebut tidak selaras bersama hasil studi Lisiantara dan Febrina (2018) juga Widhiari dan Merkusiwati (2015) yang menyatakan bahwa operating capacity mempunyai dampak signifikan padafinancial distress.

\section{Dampak Institutional Ownership pada}

\section{Financial Distress}

Hasil uji logistic regression pada variabel institutional ownership sektor pertambangan Indonesia mempunyai angka koefisiensi regresi sebesar -2,663 serta angka signifikansi sebesar $0,195<5 \%$ dari tingkat signifikansi $(\alpha)$, nilai ini memperlihatkan bahwa Ha1 ditolak atau $\mathrm{H}_{0} 1$ diterima. Hal ini memperlihatkan bahwa variabel institutional ownership (KI) tidak mempunyai pengaruh terhadap financial distress pada perseroan sektor pertambangan Indonesia tahun 20142018. Dengan demikian, uji tersebut tidak selaras pada kerangka pemikiran yang telah dibuat yakni institutional ownership mempunyai pengaruh signifikan negatif padafinancial distress. Hasil studi tersebut tidak selaras bersama hasil studi Fathanah (2016) juga Cinantya dan Merkusiwati (2015) yang mengemukakan bahwa institutional ownership memiliki dampak signifikan padafinancial distress.

Sedangkan pada sektor pertambangan Malaysia mempunyai angka koefisiensi regresi sebesar -1,746 serta angka signifikansi sebesar $0,151<5 \%$ dari tingkat signifikansi $(\alpha)$, nilai ini memperlihatkan bahwa Ha1 ditolak atau $\mathrm{H}_{0} 1$ diterima. Hal ini memperlihatkan bahwa variabel institutional ownership (KI) tidak mempunyai dampak terhadap financial distress pada perseroan sektor pertambangan Malaysia tahun 20142018. Dengan demikian, uji tersebut tidak selaras pada kerangka pemikiran yang telah dibuat yakni institutional ownership mempunyai dampak signifikan negatif padafinancial distress. Hasil studi tersebut tidak selaras bersama hasil studi Fathanah (2016) juga Cinantya dan Merkusiwati (2015) yang mengemukakan bahwa institutional ownership mempunyai dampak signifikan pada financialdistress.

\section{Dampak Managerial Ownership pada Financial Distress}

Hasil uji logistic regression pada variabel managerial ownership sektor pertambangan Indonesia mempunyai angka koefisiensi regresi sebesar 24,611 serta angka signifikansi sebesar 0,307 < 5\% dari tingkat signifikansi $(\alpha)$, nilai ini memperlihatkan bahwa Ha1 ditolak atau $\mathrm{H}_{0} 1$ diterima. Hal ini memperlihatkan bahwa variabel managerial ownership (KM) tidak 


\section{Nominal: Barometer Riset Akuntansi dan Manajemen \\ P-ISSN: 2303-2065 E-ISSN: 2502-5430 \\ Volume 10 No 2 (2021)}

mempunyai pengaruh terhadapfinancial distress pada perseroan sektor pertambangan Indonesia tahun 2014-2018. Dengan demikian, uji tersebut tidak selaras pada kerangka pemikiran yang telah dibuat yakni managerial ownership mempunyai pengaruh signifikan negatif padafinancial distress. Hasil studi tersebut tidak selaras bersama hasil studi Syofyan dan Herawaty (2019) juga Khairuddin et al., (2019) yang menyatakan bahwa managerial ownership mempunyai dampak signifikan padafinancial distress.

Sedangkan pada sektor pertambangan Indonesia mempunyai angka koefisiensi regresi sebesar $-9,167$ serta angka signifikansi sebesar $0,011<5 \%$ dari tingkat signifikansi $(\alpha)$, nilai ini memperlihatkan bahwa Ha1 diterima atau $\mathrm{H}_{0} 1$ ditolak. Hal ini memperlihatkan bahwa variabel managerial ownership (KM) mempunyai pengaruh signifikan secara negatif terhadapfinancial distress pada perseroan sektor pertambangan Malaysia tahun 2014-2018. Dengan demikian, uji tersebut selaras pada kerangka pemikiran yang telah dibuat yakni managerial ownership mempunyai pengaruh signifikan negatif padafinancial distress. Hasil studi tersebut selaras bersama hasil studi Syofyan dan Herawaty (2019) juga Khairuddin et al., (2019) yang menyatakan bahwa managerial ownership mempunyai dampak signifikan pada financial distress.

\section{Dampak Independent Comissioner pada} Financial Distress

Hasil uji logistic regression pada variabel independent comissioner sektor pertambangan Indonesia mempunyai angka koefisiensi regresi sebesar -3,002 serta angka signifikansi sebesar $0,436<5 \%$ dari tingkat signifikansi $(\alpha)$, nilai ini memperlihatkan bahwa Ha1 ditolak atau $\mathrm{H}_{0} 1$ diterima. Hal ini memperlihatkan bahwa variabel independent comissioner (KIN) tidak mempunyai pengaruh terhadap financial distress pada perseroan sektor pertambangan Indonesia tahun 2014-2018. Dengan demikian, uji tersebut tidak selaras pada kerangka pemikiran yang telah dibuat yakni independent comissioner mempunyai pengaruh signifikan negatif padafinancial distress. Hasil studi tersebut tidak selaras bersama hasil studi Fathonah (2016) juga Emrinaldi (2007) yang menyatakan bahwa independent comissioner mempunyai dampak signifikan pada financial distress.

Sedangkan pada sektor pertambangan Malaysia mempunyai angka koefisiensi regresi sebesar $-4,258$ serta angka signifikansi sebesar $0,038<5 \%$ dari tingkat signifikansi $(\alpha)$, nilai ini memperlihatkan bahwa Ha1 diterima atau $\mathrm{H}_{0} 1$ ditolak. Hal ini memperlihatkan bahwa variabel independent comissioner (KIN) mempunyai pengaruh signifikan secara negatif terhadapfinancial distress pada perseroan sektor pertambangan 
Malaysia tahun 2014-2018. Dengan demikian, uji tersebut selaras pada kerangka pemikiran yang telah dibuat yakni independent comissioner mempunyai pengaruh signifikan negatif padafinancial distress. Hasil studi tersebut selaras bersama hasil studi Fathonah (2016) juga Emrinaldi (2007) yang menyatakan bahwa independent comissioner mempunyai dampak signifikan padafinancial distress.

\section{SIMPULAN DAN SARAN}

\section{Simpulan}

Dengan demikian simpulan yang didapat dari studi ini sebagai berikut.

1. Hasil pengujian simultan memperlihatkan likuiditas (CR), leverage (DAR), operating capacity (TATO), institutional ownership (KI), managerial ownership (KM), serta independent comissioner (KIN) secara simultan mempunyai dampak pada financialdistress di perseroan sektor pertambangan yang tercatat di Bursa EfekIndonesia dan Bursa Malaysia tahun 2014-2018.

2. Hasil Pengujian Parsial

a. Liquidity tidak mempunyai dampak pada financial distress pada perseroan yang tercatat di Bursa EfekIndonesia tahun 2014-2018, namun mempunyai pengaruh secara signifikan negatif pada perseroan yang tercatat di Bursa Malaysia tahun 2014-2018.

b. Leverage tidak mempunyai dampak pada financial distress pada perseroan yang tercatat di Bursa EfekIndonesia dan Bursa Malaysia tahun 2014-2018.

c. Operating Capacity mempunyai pengaruh secara signifikan negatif pada perseroan yang tercatat di BursaEfek Indonesia tahun 20142018, namun tidak mempunyai dampak pada perseroan yang tercatat di Bursa Malaysia tahun 2014-2018.

d. Institutional Ownership tidak mempunyai dampak pada financial distress pada perseroan yang tercatat di Bursa EfekIndonesia dan Bursa Malaysia tahun 2014-2018.

e. Managerial Ownership tidak mempunyai dampak pada financial distress pada perseroan yang tercatat di Bursa EfekIndonesia tahun 20142018, namun mempunyai dampak secara signifikan negatif pada perseroan yang tercatat di Bursa Malaysia tahun 2014-2018.

f. Independent Comissioner tidak mempunyai dampak financial distresspada perseroan yang tercatat di Bursa EfekIndonesia tahun 20142018, namun mempunyai dampak secara signifikan negatif pada 
perseroan yang tercatat di Bursa Malaysia tahun 2014-2018.

\section{Saran}

1. Hasil studi ini dibuat guna dijadikan referensi bagi studi selanjutnya. Meskipun terdapat beberapa kekurangan serta keterbatasan. Oleh sebab itu disarankan adanya referensi-referensi terbaru mengenaifinancial distress.

2. Bagi studi selanjutnya disarankan menambah atau memakai variabel penelitian dan objek yang berbeda dari studi ini.

\section{DAFTAR PUSTAKA}

Cinantya, I., \& Merkusiwati, N. (2015). Pengaruh Corporate Governance, Financial Indicators, Dan Ukuran PerusahaanPada Financial Distress. EJurnal Akuntansi, 10(3), 897-915.

Elloumi, F., \& Gueyié, J. P. (2001). Financial distress and corporate governance: An empirical analysis. Corporate Governance: The International Journal of Business in Society, 1(1), 15-23.

Emrinaldi Nur D.P. (2007). Analisis Pengaruh Praktek Tata Kelola Perusahaan (Corporate Governance) Terhadap Kesulitan Keuangan Perusahaan(Financial Distress): Suatu Kajian Empiris. In Jurnal Bisnis dan Akuntansi (Vol. 9, Issue 1, pp. 88-108).

Fathonah, A. N. (2016). Pengaruh Penerapan Good Corporate Governance Terhadap Financial Distress.Jurnal Ilmiah Akuntansi, 1(2), 133-150.

Hery. (2016). Analisis Laporan Keuangan. Jakarta: PT Gramedia Widiasarana
Indonesia.

Khairuddin, F., Mahsuni, A. W., \& Afifudin. (2019). Pengaruh good corporate governance dan rasio likuiditas terhadap Financial distress di perusahaan manufaktur yang terdaftar di BEI 20152018. Jurnal Ilmiah Riset Akuntansi, 08(01), 1-13.

Komite Nasional Kebijakan Governance (KNKG). (2006). Pedoman Umum Good Corporate Governnace Indonesia.

Kristanti, F. T. (2019). Financial Distress (Teori Dan Perkembangannya Dala Konteks Indonesia). Intelegensia Media.

Kristanti, Farida Titik, Effendi, N., Herwany, A., \& Febrian, E. (2016). Does corporate governance affect the financial distress of indonesian company? A survival analysis using cox hazard model with time-dependent covariates. Advanced Science Letters, 22(12), 4326-4329.

Lisiantara, G. A., \& Febrina, L. (2018). Likuiditas, Leverage, Operating Capacity, Profitabilitas, Sales Growth Sebagai Preditor Financial Distress (Studi Empiris Pada Perusahaan Manufaktur Yang Terdaftar Di Bursa EFek Indonesia Tahun 2013-2016). Prosiding SENDI, 764-772.

Platt, H. D. \& P. M. B. (2002). Financial distress and corporate governance: an empirical analysis.Corporate Governance:The International Journal of Business in Society. Journal of Economics and Finance, 26(2), 184199.

Sugiyono. (2018). Metode Penelitian Pendidikan: Pendekatan Kuantitatif, Kualitatif, dan $R \& D$. Alfabeta. 
Susilowati, Y., Suwarti, T., Puspitasari, E., \& Nurmaliani, F. A. (2019). The Effect of Liquidity, Leverage, Profitability, Operating Capacity, and Managerial Agency Cost on Financial Distress of Manufacturing Companies Listed in Indonesian Stock Exchange. 100(2013), 651-656.

Sutedi, A. (2011).Good Corporate Governance (Edisi Pertama). Sinar Grafika.

Syofyan, A., \& Herawaty, V. (2019). Pengaruh Good Corporate Governance Terhadap Financial Distress Dengan Kualitas Audit Sebagai Pemoderasinya. Prosiding Seminar Nasional Cendekiawan, 2015, 2.

Udin, S., Khan, M. A., \& Javid, A. Y. (2017). The effects of ownership structure on likelihood of financial distress: an empirical evidence. Corporate Governance (Bingley), 17(4), 589-612. https://doi.org/10.1108/CG-03-20160067

Widhiari, N., \& Aryani Merkusiwati, N. (2015).Pengaruh Rasio Likuiditas, Leverage, Operating Capacity, Dan Sales Growth Terhadap Financial Distress. E-Jurnal Akuntansi, 11(2), 456-469.

Zhafirah \& Majidah. (2019). Analisis Determinan Financial Distress. Analisis Determinan Financial Distress, 7(1), 195-202. 